\title{
Response of neoplastic meningitis from solid tumors to oral capecitabine
}

Pierre Giglio, Ivo W. Tremont-Lukats and Morris D. Groves

Neuro-Oncology Department, University of Texas - M.D. Anderson Cancer Center, TX, USA

Journal of Neuro-Oncology 65: 167-172, 2003.

The dosing of capecitabine was misrepresented on page 168 of the original. The correct text is shown below.

p.168, 1st column, line 12 :

'... $2500 \mathrm{mg} / \mathrm{m}^{2}$ twice a day ...' should be '... $2500 \mathrm{mg} / \mathrm{m}^{2} /$ day in 2 divided doses ...'

p.168, 1st column, line 30:

'... $2500 \mathrm{mg} / \mathrm{m}^{2}$.' should be '... $2500 \mathrm{mg} / \mathrm{m}^{2} /$ day in two divided doses.'

p.168, 2nd column, line 14 from bottom:

'... $1800 \mathrm{mg} / \mathrm{m}^{2}$ twice a day ...' should be '... $1800 \mathrm{mg} / \mathrm{m}^{2} /$ day in 2 divided doses ...'

p.168, 2nd column, lines 11-12 from bottom:

‘... $2000 \mathrm{mg} / \mathrm{m}^{2}$ twice a day ...' should be '... $2000 \mathrm{mg} / \mathrm{m}^{2} /$ day in 2 divided doses ...' 